\title{
Fractionation of fish protein hydrolysates by ultrafiltration and nanofiltration: impact on peptidic populations
}

\author{
P. Bourseau ${ }^{a, b, ~}{ }^{*}$, L. Vandanjon ${ }^{a, b}$, P. Jaouen ${ }^{a}$, M. Chaplain-Derouiniot ${ }^{a}$, A. Massé ${ }^{a}, F$. \\ Guérard $^{c}$, A. Chabeaud ${ }^{b, c}$, M. Fouchereau-Péron ${ }^{d}, Y$. Le Gal ${ }^{d}$, R. Ravallec-Plée , J.-P. Bergéf, \\ L. Picot ${ }^{g}$, J.-M. Piot ${ }^{g}$, I. Batista ${ }^{h}$, G. Thorkelsson', C. Delannoyj, G. Jakobsen ${ }^{\mathrm{k}}$ and I. \\ Johansson $^{\mathrm{k}}$
}

\author{
a UMR CNRS 6144 GEPEA, Université de Nantes, Saint-Nazaire, France \\ b LIMATB, Université Européenne de Bretagne, UBS, Rue de Saint-Maudé, BP 92116, 56321 Lorient Cedex, \\ France \\ c Laboratoire ANTIOX, Université de Bretagne Occidentale, Quimper, France \\ d UMR 5178 CNRS/MNHN/UPMC, Station de Biologie Marine, Concarneau, France \\ e ProBioGEM, Polytech' Lille, USTL, France \\ ${ }^{\dagger}$ IFREMER, STAM, Nantes, France \\ ${ }^{9}$ LBCB, Université de La Rochelle, France \\ h Ipimar, Lisbon, Portugal \\ Matis ohf, Reykjavik, Iceland \\ ${ }^{j}$ Copalis-CTPP, Boulogne sur Mer, France \\ ${ }^{k}$ Marinova, Højmark, Denmark
}

*: Corresponding author :
patrick.bourseau@univ-ubs.fr

\begin{abstract}
:
The production by enzymatic treatment of fish protein hydrolysates $(\mathrm{FPH})$ is a promising route to add value to fisheries proteinic co-products (fish frames, heads etc.). Indeed, FPH possess good nutritional properties and biological activities for food and feed uses. Pressure-driven membrane separations such as ultrafiltration (UF) and nanofiltration (NF) can be used after the hydrolysis to increase the specific activities of the FPH. This paper discusses the impact of a two-step UF/NF process producing four different fractions on two industrial FPH with different hydrolysis degrees. Fractionation is carried out in "realistic" conditions for an industrial process, on highly concentrated FPH solutions (about 100 $\mathrm{g}$ of dry matter/L) at a high volume reduction factor. For each step, UF or NF, the variation of the permeation flux in the course of the fractionation is discussed according to the FPH hydrolysis degree and the membranes cut-offs. The values of performance indicators defined in terms of nitrogen content are also examined, including the concentration factor $(C F)$, the relative recovery in the retentate $\left(\eta_{R}\right)$ and the mean and final retention factors $\left(R F_{m}\right.$ and $\left.R F_{f}\right)$. Computed values of these indicators are validated through the setting of volume and mass balances around each step. The impact of fractionation on the FPH peptidic population is shown. Peptidic populations are described in terms of chromatographic profiles (SEC-FPLC). The UF fractionation produces a permeate enriched with respect to the FPH smaller than a molecular weight of about 600-750 Dalton, and a retentate enriched in large peptides (above the same MW). A similar behaviour is found for the NF fractionation. Comparing the impact of the UF fractionation on the two hydrolysates allows to conclude that the membrane cut-off is well-suited when comprised between the MWs of the biggest and the most abundant peptides in the FPH.
\end{abstract}

Keywords: Fish protein hydrolysate; FPH; Ultrafiltration; Nanofiltration; Membrane separation; Fractionation process; Peptidic profile 


\section{Introduction}

Membrane separations are useful techniques to extract, concentrate, purify or fractionate valuable marine molecules from effluents, wastes or by-products from seafood processing industries. Some works have been carried out to upgrade liquids effluents by recovering proteins [1], aromas [2, 3] or polysaccharides [4]. On the other hand, considerable amounts of solid by-products are produced yearly. Indeed, world fisheries came in 2004 to about 140 million tons and only $75 \%$ were used as food, leaving about 35 millions tons for non-food uses [5], a small part being even discarded (7.3 millions tons in 2004, [6]). Solid by-products such as filleting wastes or heads are usually converted to fish meal and oil for feed with a low addedvalue, but better upgrading must be researched. A promising route is to proceed them through enzymatic hydrolysis operated in mild controlled conditions to produce fish protein hydrolysates (FPH) with excellent nutritional properties and/or interesting biological activities for nutritional uses (food, feed or pet-food) [7-10].

Obtaining high bioactivities from a given substrate is mainly controlled by the enzyme specificity and hydrolysis conditions ( $\mathrm{pH}$, temperature, enzyme-to-substrate ratio, and hydrolysis degree) [11-17]. The relation between the structure of peptides and their activities is not known in detail but depends from various characteristics, amino-acid sequence, molecular weight (MW), hydrophobicity, charge and acido-basic character [18]. Peptides MW has in particular a great impact so that pressure-driven membrane separations can be used as a second control step to increase their specific activity (i.e. per gram of peptide).

Membrane separations are widely used in industry to concentrate, refine and desalt, or fractionate food and biotechnological solutions. They have been used for a couple of decades to treat protein hydrolysates of dairy origin [19-23], and animal [24] or vegetable products [25-27]. Some works were more recently carried out on marine hydrolysates [28-31]. In the majority of these works, dilute hydrolysates (about $1 \mathrm{w} / \mathrm{v} \%$ or less) are processed either at total recycling or at a low volume reduction factor (VRF). But fractionation at an industrial scale of dilute hydrolysates at low VRF will induce low productivity, require large membrane surface area, and will be therefore economically feasible only for high added-value products.

On the other hand, most industrial hydrolysates sold for cosmetic or food purposes are produced at quite high concentration (few dozen $\mathrm{w} / \mathrm{v} \%$ ) and membrane fractionation must probably be led at quite high VRF to be economically feasible. In such conditions, charge or hydrophobic effects are masked and the fractionation selectivity is mainly related to the peptides size. According to their Molecular Weight Cut-Off (MWCO), UF or NF of peptide hydrolysates have been suggested for various purposes. NF can be used to concentrate hydrolysates [26, 31, 32], whereas UF membranes with high MWCO (20 to $100 \mathrm{kDa}$ ) are adapted to the separation of peptides and non-hydrolyzed proteins or proteolytic enzymes [33, 34]. On the other hand, UF membranes with intermediate MWCO (about 4000 to $8000 \mathrm{Da}$ ) allow hydrolysates to be fractionated with the result of enrichment in some ranges of molecular weight [31].

In this paper, two industrial hydrolysates are fractionated by a 2-step process consisting of an ultrafiltration (MWCO $4000 \mathrm{Da}$ ) followed by a nanofiltration. The fractionation is performed in conditions close to industrial ones, starting from concentrated hydrolysates $(100 \mathrm{~g} / \mathrm{L}$ of dry matter) and being led to a high VRF (6.0 to 10.6). Studies in such conditions have been seldom reported [19, 31]. Performances of the UF/NF fractionation such as permeation fluxes and retention factors are discussed for the two hydrolysates and compared. The composition in peptides of hydrolysates and the fractions resulting from the UF-NF sequence are characterized by SEC-FPLC chromatograms, and the impact of the fractionation is discussed on the basis of these chromatograms. It is shown that this impact depends on the molecular weight range in the hydrolysates. 


\section{Materials and methods}

\subsection{Fish protein hydrolysates}

PROLASTIN (FPH1), a commercial hydrolysate from Copalis, Boulogne/mer, F-62203-France, is sold for cosmetic and dietetic purposes. It is a hydrolysed elastin obtained by enzymatic hydrolysis of the connective tissues of specific species of fish. PROLASTIN is composed of polypeptides with a low molecular weight (1000 to 5000 Dalton), which makes it soluble and very digestible. Elastin is one of the main proteins of connective tissues and ligaments and is rich in some amino acids: proline, leucine, isoleucine, alanine and valine. PROLASTIN helps to give elasticity to tissues and limits their ageing.

MariPep C (FPH2), a commercial hydrolysate from Marinova, Danish Fish Protein, Hoejmark, DK-6940-Denmark, is obtained by hydrolysis of specific parts from Cod. MariPep C is composed of polypeptides and free amino acids and is sold as functional ingredient to the food industry. MariPep $\mathrm{C}$ is known to have antioxidant, emulsifying and freeze stabilizing properties. Hydrolysates were provided as powders. The fractionation process has been fed with "crude extract" obtained by dissolving about $100 \mathrm{~g} / \mathrm{L}$ of powder in pure water.

\subsection{Analyses}

Nitrogen content (NK) of samples was determined by the Kjeldahl method (mineralization by Selenium) following the norm NF EN 25663 ISO 5663 [january 1994].

The molecular weight distributions of native hydrolysates and UF/NF fractions were obtained by size exclusion chromatography in FPLC mode using a Superdex Peptide ${ }^{\circledR}$ HR 10/300 column (Amersham, fractionation range: 7000-100 Da) according to Guérard et al. [35]. The liquid chromatographic system consisted of a Waters 600 automated gradient controller pump and a Waters 996 photodiode array detector. Data acquisition and chromatographic analysis were performed with Empower ${ }^{\circledR}$ software. $20 \mu \mathrm{L}$ of hydrolysate $(30 \mathrm{mg} / \mathrm{mL}$ in MilliQ water), sterile filtered, were injected into the column, and elution was carried out isocratically in MilliQ water with TFA $0.1 \%$ and acetonitrile $(70: 30)$ at a flow rate of $0.5 \mathrm{~mL} / \mathrm{min}$. Standards used for the calibration were aprotinin (6512 Da), chain B insulin (3495.9 Da), chain A insulin (2531.6 Da), neurotensin $(1672.9 \mathrm{Da})$, substance $\mathrm{P}(1347.6 \mathrm{Da}), \mathrm{LH}-\mathrm{RH}(1182.3 \mathrm{Da})$, substance $\mathrm{P}$ fragment 1-7 (900 Da), leupeptin (463 Da), and glycin $(75 \mathrm{Da})$. The total area of the chromatogram was integrated and separated into fractions of five molecular weight (MW) ranges $(>7000,7000-$ $4000,4000-1000,1000-500,500-300$, and < $300 \mathrm{Da}$, respectively), expressed as the percentage of the total area.

Two kinds of chromatograms were used in this study. First, samples were injected at their native concentration. These "raw" chromatograms were used to determine the nitrogen content. Indeed, previous works [36] have shown that the total area under chromatograms could be strongly correlated to the NK amount in the sample injected in the column. The total area of the chromatogram has thus been used in this work to determine a second value of NK contents in samples for security.

Then, samples were diluted so that the mass injected was exactly the same for each sample. The "normalized" chromatograms obtained in this way are representative of the mass composition (in the sense of mass fractions) of the samples and are more expressive than "raw" chromatograms to analyze the impact of a membrane fractionation. Only "normalized" chromatograms are presented in this paper. 


\subsection{Membrane processes}

Crude extracts of FPH1 and FPH2 were fractionated successively by UF and NF, the UF permeate being used as the feed solution for the following NF step (see Figure 1). Experiments were carried out on a Microlab40 pilot plant (VMA Industrie, Meung sur Loire, France) with a maximum capacity of $5 \mathrm{~L}$ (launching tank $4.3 \mathrm{~L}+$ dead volume $0.7 \mathrm{~L}$ ). The pilot plant was equipped with tubular organic membranes (PCl Ltd), diameter $12 \mathrm{~mm}$, surface area $0.033 \mathrm{~m}^{2}$ : an NF membrane in Polyamide coated on Polyethersulfon (60\% retention in $\mathrm{CaCl}_{2}$, ref. AFC40) and a UF membrane in modified Polyethersulfon (MWCO $4000 \mathrm{Da}$, ref. ESP04). New membranes were used for nanofiltration of $\mathrm{FPH} 1$ and $\mathrm{FPH} 2$, whereas ultrafiltrations were performed with the same membrane that was chemically well-cleaned between the two filtrations.

The ESP04 UF membrane has been chosen in the $\mathrm{PCl}$ range according to the molecular weight distribution of the hydrolysates. It will be proved further that a nominal MWCO between the molecular weight of the biggest and the medium-size peptides is a good choice for the fractionation of a hydrolysate. The AFC40 NF membrane has been selected as it has the lowest salt retention in the $\mathrm{PCl}$ range, which makes it the most appropriate to fractionate UF permeates. An MWCO of about 300 Da has been estimated by the membrane supplier for the fractionation of organic molecules onto this NF membrane.

A volume of $10 \mathrm{~L}$ of solution was prepared by mixing $100 \mathrm{~g}$ of hydrolysate powder in pure warm water. A $1 \mathrm{~L}$-aliquot is reserved for analysis. So, $9 \mathrm{~L}$ of the initial solution are filtered with the $4000 \mathrm{Da}$ membrane in a semi-continuous mode by feeding the launching tank during a part of the filtration. At the end of the concentration process, volumes of about $8 \mathrm{~L}$ of average permeate and $1 \mathrm{~L}$ of retentate are recovered. The whole retentate is kept for analysis, as well as a sample of about $1 \mathrm{~L}$ of the permeate. The remaining permeate $(7 \mathrm{~L})$ constitutes the initial solution filtered by NF in the second stage of the fractionation cascade. One obtains in this way about 6 $\mathrm{L}$ of average permeate and $1 \mathrm{~L}$ of retentate which are kept for analysis. At the end of each filtration step, a sample of 10 to $50 \mathrm{~mL}$ of "instantaneous" permeate is reserved in order to estimate the retention factor at the end of this operation (this sample will be called "final permeate" in the paper, the term "permeate" being kept to name the average permeate over the fractionation step).

Filtrations were carried out in the following operating conditions: tangential velocity $V=2.5 \mathrm{~m} / \mathrm{s}$, temperature $\mathrm{T}=55{ }^{\circ} \mathrm{C}$, transmembrane pressure $\Delta \mathrm{P}=30$ bar for UF or 35 bar for NF. The selected values for $\mathrm{V}$ and $\Delta \mathrm{P}$ were the maximal ones allowed by the pilot and the membrane, in order to minimise the filtration time. However, filtration times were rather long because high volumic reduction factors were reached. Thus, quite high temperature was chosen in order to maximize permeation fluxes, as well as to limit bacterial growth. It should be noted that hydrolysates are produced at quite higher temperatures so that filtering hydrolysates at $55^{\circ} \mathrm{C}$ should not involve degradation of the product.

According to the membrane supplier recommendations, new membranes were "conditioned" before being used following the sequence: water - Ultrasil 11 - water - nitric acid - water. The UF membrane was first used to fractionate FPH1 and then reused for FPH2 after being cleaned by the following protocol: water rinsing (about 10 min at $30^{\circ} \mathrm{C}$ ) - washing with Ultrasil 11,10 $\mathrm{g} / \mathrm{L}, 15 \mathrm{~min}$ at $50^{\circ} \mathrm{C}$ - water rinsing (about $10 \mathrm{~min}$ at $30^{\circ} \mathrm{C}$ ). Two different membranes was used to fractionate FPH1 and $\mathrm{FPH} 2$ by nanofiltration but the same UF membrane was used for all the runs because it was completely regenerated after cleaning.

\subsection{Calculation of performance indicators}

For each step, the volume reduction factor VRF and the concentration factor in nitrogen CF were computed as well as the observed retention factor, either on average over the filtration or 
at its end (resp. $R F_{m}$ and $R F_{f}$ ), and the relative recovery of peptides in the retentate $\eta_{R}$. These performance indicators are defined as:

$$
V R F=\frac{V_{0}}{\left(V_{0}-V_{p}-V_{p}^{\prime}\right)}
$$

$$
C F=\frac{C_{R}}{C_{0}}
$$

(3)

$$
R F_{m}=\frac{\ln F C}{\ln V R F}
$$

$$
\begin{aligned}
& R F_{f}=1-\frac{c_{P f}}{c_{R}} \\
& \eta_{R}=\frac{m_{R}}{m_{R}+m_{P}}
\end{aligned}
$$

where $V_{0}, V_{p}, V_{p^{\prime}}$ are respectively the volumes of the solution filtered, the average permeate over the filtration and the final permeate sample; $c_{0}, c_{R}$ and $c_{P f}$ are the mass concentrations (in $\mathrm{NK}$ ) of the solution filtered, of the concentrate recovered after filtration and of the final permeate sample; $m_{R}$ and $m_{P}$ are the masses of NK recovered in the retentate and in the permeate.

$V R F, C F$ and $R F_{m}$ are global indicators on the whole extent of the separation, and the comparison of the final retention factor $R F_{f}$ with the mean factor $R F_{m}$ gives information on the drift in peptides retention along the filtration.

\subsection{Volume and mass balances}

The precision of the balance in some amount $X$ (volume or nitrogen amount) was quantified by the relative error defined as the ratio of the residue of $X$ around the fractionation operation to the initial amount of $\mathrm{X}$, expressed in percentage:

$$
\varepsilon(X)=\frac{X(f s)-X(\text { retentate })-X(\text { mean permeate })-X(\text { final permeate })}{X(f s)} \times 100 \%
$$

were « $f S$ » stands for « solution to be filtered» (either the raw hydrolysate for UF steps or the UF permeate for the NF steps), X(fs) for "the amount of X in the filtered solution", ...).

Filtration performances and nitrogen balances were computed on the basis of Kjeldhal measurements. Nitrogen contents estimated from chromatograms areas were considered as control values when uncertain results were obtained on the basis of Kjeldahl measurements.

\section{Results and discussion}

\subsection{Characterization of hydrolysates and fractions}

The physical properties of hydrolysates and fractions obtained by UF/NF fractionation are reported on Table 1 and their discrete size-distributions on Table 2. FPH1 is clearly more 
hydrolyzed than FPH2 as it can be seen by comparing their discrete size-distributions. Indeed, only $1.4 \mathrm{w} / \mathrm{w} \%$ of peptides in FPH1 have a molecular weight greater than $4000 \mathrm{Da}$ instead 9.4 $\%$ in FPH2. In addition the main amount of peptides is between 300 and $1000 \mathrm{Da}$ for FPH1 but between 1000 and $4000 \mathrm{Da}$ for FPH2 (comparing curves $\mathrm{n}^{\circ} 2$ on Figures 3 and 5 shows also the higher degree of hydrolysis of $\mathrm{FPH} 1$. In addition, the two hydrolysates have different contents in chloride and salt: FPH1 (elastine) is hardly salted $(0.73 \mathrm{w} / \mathrm{w} \%$ of $\mathrm{NaCl})$ whereas $\mathrm{FPH} 2$ (cod) is much more $(19.5 \mathrm{w} / \mathrm{w} \%$ of $\mathrm{NaCl})$.

\subsection{Permeation fluxes}

Table 3 gathers the main performances of UF and NF for the two hydrolysates by reporting their duration, volume reduction factor (VRF), concentration factor (CF), mean and final retention rate $\left(R F_{m}\right.$ an $\left.R F_{f}\right)$, relative recovery of peptides in the retentate $\left(\eta_{R}\right)$, water permeabilty values measured before each filtration $\left(L_{p}\right)$, permeation fluxes at the beginning and at the end of the filtration $\left(J_{v, i}\right.$ and $\left.J_{v, f}\right)$ and initial permeability $\left(J_{v i} / \Delta P\right)$.

Fractionations were carried out to the maximum extend, e.g. until low permeation fluxes were reached or the retentate volume became equal to the dead volume. In this way, VRF of 8.2 and 10.6 were respectively obtained for the ultrafiltration of FPH1 and FPH2, and VRF of 8.3 and 6 for the nanofiltration step. Permeation fluxes decrease similarly in the course of UF or NF fractionation. (see Figure 2 for FPH1).

\section{Ultrafiltration steps}

It appears that permeation flux kept the same order of magnitude for both hydrolysates during the UF step. They sharply decreased from 100 to $20 \mathrm{~L} \cdot \mathrm{m}^{-2} \cdot \mathrm{h}^{-1}$ for FPH1 (factor 5) and from 105 to $10 \mathrm{~L} . \mathrm{m}^{-2} \cdot \mathrm{h}^{-1}$ for $\mathrm{FPH} 2$ (factor 10 ). This observation is not surprising because highly concentrated FPH with large MW ranges were filtered at a high VRF. Now, it is well-known that permeation flux in ultrafiltration decreases as the solutes concentration increases, because of the two following mechanisms [37]: i) the increase in solutes concentration near the membrane results in a significantly higher osmotic pressure $\Delta \Pi$, causing a decrease in the driving force $(\Delta \mathrm{P}$ $-\sigma \Delta \Pi$ ) (even if the osmotic pressure of the feed solution is quite low, the increase in concentration at the membrane wall can be quite important and $\Delta \Pi$ may become nonnegligeable) - ii) the increase in the hydraulic resistance of the boundary layer. This decrease in permeation flux as the solutes concentration increases is all the more marked as the filtration is carried out at high pressure and in the mass-transfer controlled region, which is the case in this work.

\section{Nanofiltration}

As for UF, permeation flux kept the same order of magnitude for both hydrolysates and decreased strongly during the nanofiltration. Permeation fluxes were a bit greater and flux decline markedly lower for $\mathrm{FPH} 2$ although the UF permeate is strongly more salted for $\mathrm{FPH} 2$. So, the flux declined from 120 to $8 \mathrm{~L} \cdot \mathrm{m}^{-2} \cdot \mathrm{h}^{-1}$ for FPH1 (factor 15) and from 160 to $26 \mathrm{~L} \cdot \mathrm{m}^{-2} \cdot \mathrm{h}^{-1}$ for $\mathrm{FPH} 2$ (factor $\approx 6$ ) (table 3 ). It can be related to the fact the concentration of the filtered solution was quite lower for FPH2 (UF permeate concentration $=3.77 \mathrm{~g} \cdot \mathrm{L}^{-1}$ for $\mathrm{FPH} 2$ but 9.89 g. $\mathrm{L}^{-1}$ for $\mathrm{FPH} 1$, table 4, column $\mathrm{C}_{1}$ ). In addition, hydrolysate $\mathrm{FPH} 1$ was more hydrolyzed (table 2) and thus contained less bigger peptides and more smaller ones, so that UF was easier and NF more difficult. 
Salt content may also have an influence on nanofiltration fluxes, $\mathrm{FPH} 2$ being very more salted than FPH1. But this influence is probably moderate as the NF membrane is quite loose (60\% $\mathrm{CaCl} 2$ retention, retention in $\mathrm{NaCl}$ unknown but quite low).

UF and NF are performed to their maximum extent, leading to high final concentrations (above $350 \mathrm{~g} . \mathrm{L}^{-1}$ for some steps) and very low permeation fluxes at the end of the filtration. In addition high transmembrane pressures are used. Despite these drastic conditions favoring the membrane fouling, fouling deposits seemed at first sight correctly shift by the cleaning procedure followed (both for UF and NF).

Only a few works reported permeation flux values for hydrolysates filtration at high concentration and high VRF. On the other hand, works must be compared with precaution because many parameters have an influence on permeation fluxes: membrane material and permeability, temperature and hydrodynamic parameters (tangential velocities and transmembrane pressure), hydrolysate nature (hydrolysis degree, existence or not of pretreatment such as centrifugation or microfiltration), hydrolysate concentration and salt contents, and physicochemical environment $(\mathrm{pH}$ in particular. Gourley et al.[19] reports the ultrafiltration of casein hydrolysates with 4 organic plane membranes at intermediate VRF and at various $\mathrm{pH}$ (Iris, polysulfone-PS- and polyethersulfone-PES-, MWCO 5000 and $10000 \mathrm{Da}, \Delta \mathrm{P}=1.6$ bar, $\mathrm{C}_{0}=1.65 \mathrm{w} / \mathrm{v} \%$ total solids). For a PES $5000 \mathrm{Da}$ membrane (close to that used in this work, i.e. $4000 \mathrm{Da}$ ), they report at $\mathrm{pH} 8$ an initial permeability $\mathrm{J}_{\mathrm{v}, \mathrm{l}} / \Delta \mathrm{P}$ of $18.75 \mathrm{~L} \cdot \mathrm{m}^{-2} \cdot \mathrm{h}^{-1} \cdot \mathrm{bar}^{-1}$, and a flux declines $J_{V, i} / J_{v, f}$ of about 2.1 at VRF of 1.6; they note also a strong influence of $\mathrm{pH}$ on the permeation fluxes, the initial permeability lowering from 18.75 to $6.25 \mathrm{~L} \cdot \mathrm{m}^{-2} \cdot \mathrm{h}^{-1} \cdot \mathrm{bar}^{-1}$ when $\mathrm{pH}$ falls from 8 to 6 . Initial values of permeability are quite lower in the present work, as $J_{v, i} / \Delta P=3.3$ L. $\mathrm{m}^{-2} \cdot \mathrm{h}^{-1} \cdot$ bar $^{-1}$ for the least salted hydrolysate (FPH1 - PROLASTIN, table 3, last column). It can be explained because (i) a hydrolysis degree quite higher in [19] (96.3\% peptides lower than $2000 \mathrm{Da}$ ), and (ii) a high transmembrane pressure and thus a more marked fouling in the present work. Flux decline $J_{V, i} / J_{v, f}$ is also greater in the present work (5 instead 2.1), the main reason being that a larger VRF was achieved in the present work.

The most similar study, reported by Vandanjon et al. [31], concerns the filtration of a hydrolysate of blue whiting protein isolate having a peptic profile of the hydrolysate close to that of $\mathrm{FPH} 2$ by the same UF and NF membranes. For the UF step, they reported a permeability increasing from 2.4 to $2.85 \mathrm{~L} \cdot \mathrm{m}^{-2} \cdot \mathrm{h}^{-1} \cdot \mathrm{bar}^{-1}$ as the pressure increased from 12 to $20 \mathrm{bar}\left(\mathrm{T}=15^{\circ} \mathrm{C}, \mathrm{c}_{0}=0.48 \mathrm{w} / \mathrm{v}\right.$ $\%, \mathrm{~V}=2.5 \mathrm{~m} \cdot \mathrm{s}^{-1}$, permeation flux measured at total recycling after $2 \mathrm{~h}$ ) that are very similar to those in the present work. They report also for the nanofiltration of the hydrolysate at high concentration and high VRF $\left(\mathrm{C}_{0}=45.3 \mathrm{~g} \cdot \mathrm{L}^{-1}\right.$ and $\mathrm{FRV}=6.7 ; \mathrm{T}=40^{\circ} \mathrm{C}, \Delta \mathrm{P}=35$ bar $)$ an initial permeability $J_{V, i} / \Delta P=2.9 \mathrm{~L} \cdot \mathrm{m}^{-2} \cdot \mathrm{h}^{-1} \cdot \mathrm{bar}^{-1}$ and a flux decline $\mathrm{J}_{\mathrm{V}, \mathrm{l}} / \mathrm{J}_{\mathrm{V}, \mathrm{f}}=5$ shlightly lower than those observed here $\left(\mathrm{J}_{\mathrm{v}, \mathrm{l}} / \Delta \mathrm{P}=3.4\right.$ for $\left.\mathrm{FPH} 1-\mathrm{PROLASTIN}\right)$. The lower flux decline could be explained by the fact that the protein isolate hydrolystae induce a lower fouling than those produced from wastes used in the present work.

\subsection{Mass balances on NF and UF steps}

The volumes, nitrogen concentrations and nitrogen masses in hydrolysates and their fractions are reported on Table 4. It can be seen that similar values of nitrogen content were obtained either by the Kjeldahl method or by chromatograms areas measurement, except for UF retentates. Indeed, discrepancies for the other fractions are less than $1.8 \mathrm{~g} \cdot \mathrm{L}^{-1}$ of NK as they are much larger for UF retentate (9.81 for FPH1 and 6.0 for FPH2).

The values of performance indicators discussed in $\S 3.4$ were computed by assuming that volume and mass amounts were balanced for each fractionation. Correct interpretation of these indicators - and of the separation performance - depends on these balances, the precision of 
which must be discussed. Our experience is that it is not easy to have a sharp precision in mass balance on filtration at high VRF. Indeed, there are several causes of discrepancy: in particular, some materials can be adsorbed on membrane, pipe or vessel walls, or can be accumulated into the dead volume (At the end of the experiment, the major part of dead volume can be recovered, but a small volume of retentate always remains in pipes or in the pump housing, about a few tens of $\mathrm{mL}$ ). Thus, there is no reason masses should be exactly balanced, and one can expect on the contrary that the residues of the mass balances will be positive. However, the moderate precision of nitrogen measurements may overcome these causes of discrepancy and lead to negative values for residues. Nitrogen masses being computed as the product (concentration $\times$ volume), masses in permeates were probably determined less accurately than in retentates because of their low concentrations.

Volumes were balanced precisely for the four filtration steps (table 4), the maximum error being $2 \%$. Nitrogen contents for elastin hydrolysate FPH1 fractionation were well-balanced on the NF step (5\%), and reasonably balanced for the UF step (9.5\%). The precision of the Nitrogen mass balance on NF was also good for the cod hydrolysate FPH2 $(0.2 \%$, see table 4 , line "NF balance residues") but less good for the UF step (19.6\%). Similar precisions on mass balances are obtained when using Nitrogen determinations by SEC-FPLC or the Kjeldahl method.

\subsection{Volume reduction (VRF), concentration factor (CF), relative recovery $\left(\eta_{R}\right)$ and mean and final retention factors $\left(R_{m}\right.$ and $\left.R F_{f}\right)$}

As for fluxes, differences in observed values of VRF, $C F$ and $R F_{m}$ between hydrolysates FPH1 and $\mathrm{FPH} 2$ can be explained by the fact FPH1 is more hydrolyzed (table 2). A high VRF could be achieved during the UF step for FPH1 (VRF = 10.6), but with quite moderate CF and $R F_{m}$ (resp. 3.4 and $52 \%$ ) (table 3). A smaller VRF value (6) was obtained for the NF step because the solution filtered has a higher content in big peptides, but with high concentration and mean retention factors $\left(C F=4.6\right.$ and $\left.R F_{m}=85 \%\right)$.

The UF step was more difficult for FPH2 (less hydrolyzed) than for FPH1. Consequently, the VRF reached was lower (8.2 instead 10.6), but higher $C F$ and $R F_{m}$ were achieved $\left(R F_{m}=69 \%\right.$ instead of $52 \%$ ). On the contrary, NF was more easy than for FPH1, and a higher VRF was reached (8.3 instead of 6 for $F P H 1$ ) with higher $C F$ and $R F_{m}\left(R F_{m}=93 \%\right.$ instead of $85 \%$ for FPH1).

As a consequence of the difference in hydrolysis degrees, the relative recoveries of peptides in the retentate were very different for the UF step $\left(\eta_{R}=31 \%\right.$ for $\mathrm{FPH} 1$, the most hydrolyzed, and $64 \%$ for $\mathrm{FPH} 2$ ). On the contrary, the relative recoveries were very close for the nanofiltration steps (77 \% for FPH1 and $71 \%$ for FPH2) since UF permeates had the same MW ranges.

It is worth noting that very high concentrations were obtained for each step except for the NF of hydrolysate $\mathrm{FPH} 2$. Indeed, concentrations in retentates ranged from 45 to $49 \mathrm{~g} \cdot \mathrm{L}^{-1}$ of NTK corresponding to concentrations in dry matter greater than $350 \mathrm{~g} \cdot \mathrm{L}^{-1}$. Probably it would be necessary to be content with lower concentrations at an industrial scale, because these high values were obtained with quite low permeation fluxes that are not realistic from an economic point of view. Taking a decision can be done on the basis of a technical and economic study of the process - see for instance [38] for such a study applied to the concentration of marine cooking juices by reverse osmosis -.

Table 3 also reports the value of the retention factors at the end of filtrations, $R F_{f}$. For hydrolysate $\mathrm{FPH} 1$, it appears that these values were markedly lower than the mean values over the filtrations, $R F_{m}$ : thus, $R F_{f}=30 \%$ and $R F_{m}=52 \%$ for the UF step; $R F_{f}=60 \%$ and $R F_{m}=85$ $\%$ for the NF step. A similar behaviour was observed for the NF of hydrolysate FPH2, although less marked, probably because the concentration at the end of this step was lower $\left(R F_{m}=93\right.$ $\%, R F_{f}=85 \%$ and $c_{R}=27.1 \mathrm{~g} \cdot \mathrm{L}^{-1}$ instead of $45.1 \mathrm{~g} \cdot \mathrm{L}^{-1}$ for FPH1). For the UF of FPH2, $R F_{f}$ was 
however very close to $R F_{m}$ (resp. 71 and $69 \%$; unexpectedly, $R F_{m}$ is lower than $R F_{f}$, probably due to experimental uncertainties).

The retention factors for $\mathrm{FPH} 2$ can be compared with those given by Vandanjon et al. [31] for the same UF and NF membranes and a hydrolysate similar to FPH2. These authors ultrafiltrate the hydrolysate at total recycling $\left(\mathrm{c}_{0}=4.8 \mathrm{~g} \cdot \mathrm{L}^{-1}\right)$ and nanofiltrate it at high concentration $\left(\mathrm{c}_{0}=\right.$ $\left.45.3 \mathrm{~g} \cdot \mathrm{L}^{-1}, \mathrm{VRF}=6.7\right)$. For the UF at total recycling, they obtained a RF of $80 \%(\mathrm{VRF}=1)$ which is coherent with the lower value obtained in this work for the mean retention factor $\left(R F_{m}=\right.$ $69 \%$ at VRF = 8.2), inasmuch as RF decreases when VRF increases. They found the RF remained almost constant during the nanofiltration at 97-98 \%. It is normal that the retention is lower in the present work $\left(R F_{m}=93 \%, R F_{f}=85 \%\right)$ because the ultrafiltrate passed through the nanofiltration membrane contain quite smaller peptides. On the other hand, retention factors found by Gourley for a more hydrolysazed product with a UF $5000 \mathrm{Da}$ membrane $\left(\mathrm{c}_{0}=4.8 \mathrm{~g} \cdot \mathrm{L}^{-1}\right.$, $\mathrm{VRF}=4$, see $\S 3.2$ for other conditions) was unsurprisingly much smaller, 0.15 and 0.02 resp. at $\mathrm{pH} 6$ and 8.

The decrease in the apparent retention factor $\left(R_{a}=1-c_{p} / c_{0}\right)$ when the solutes concentration increased can be explained by the influence of the concentration polarization phenomenon on solutes retention and by the evolution of the polarization phenomenon as the solutes concentration increases. Polarization phenomenon is defined as the accumulation near the membrane wall of molecules that are totally or partially retained. Thus, the solution is more concentrated in the boundary layer near the membrane wall than in the bulk. As the concentration in solutes at the membrane wall $\left(c_{m}\right)$ is greater than in the bulk solution flowing along the membrane $\left(c_{0}\right)$, the apparent retention factor $R_{a}$ is lower than the true retention factor $\left(R_{t}=1-c_{p} / c_{m}\right)$.

Polarization tends to increase with the bulk concentration $c_{0}$ because the increase of viscosity at the membrane wall weakens the retrodiffusion counteracting the accumulation of solutes at the membrane wall. This leads $R_{a}$ to move away from $R_{t}$ and thus $R_{a}$ to decrease. On the other hand, the layer formed at the membrane wall can become fairly viscous or gelatinous enough to act as a second "dynamic" membrane more compact and less permeable to solutes than the physical membrane. In such a case, the polarization tends to increase both the true retention factor $R_{t}$ and the apparent one $R_{a}$. Thus, as $c_{0}$ increases more solutes pile up near the membrane but this effect can possibly be competed by the formation of a compact dynamic membrane increasing the filtering capacity. According to whether the first or the second effect dominates, an increase in the polarization will involve a reduction or an increase in the apparent retention factor. As it was observed in the experiments reported here that the apparent retention decreased as $c_{0}$ increased and as the permeation flux $J_{v}$ decreased (see $\S$ "Permeation fluxes"), it can be concluded that the main effect is the larger accumulation of solutes at the membrane wall.

\subsection{Impact of UF and NF fractionation on the peptidic population}

Figures 2 to 5 show the chromatograms of fractions involved in the fractionation of hydrolysates $\mathrm{FPH} 1$ and FPH2 by the UF-NF sequence described on Figure 1. Discrete size-distribution of the hydrolysates and their UF and NF fractions are also given on table 2.

\subsubsection{Cod hydrolysate FPH2 (Figures 3 and 4)}

Figure 3 clearly shows the effect of FPH2 fractionation by UF. Almost all the peptides above $4000 \mathrm{Da}$ were retained by the membrane so that the retentate was enriched in large and 
medium-size peptides. More precisely, the retentate was here enriched in peptides larger than $750 \mathrm{Da}$ (which is the abscissa where retentate and FPH1 curves cross). It can be seen that the separation was not very sharp despite the high FRV reached. Indeed, the retentate still contained many peptides inferior to $4000 \mathrm{Da}$ because only very small peptides (<300 Da) passed freely through the membrane. As for the permeate, it can be seen that it was almost totally free from peptides above $4000 \mathrm{Da}$ and enriched in small peptides below $750 \mathrm{Da}$. The permeate and FPH2 curves are clearly different, meaning that the fractionation is really effective.

It is worth noting that the permeate and the retentate curves cross the hydrolysate curve at very close molecular weights (about $750 \mathrm{Da}$ ). This value can be considered as the "pivot" point of the fractionation, meaning that the operation produced two fractions enriched or lowered in peptides above these pivot points.

Similar observations can be done for the NF fractionation of the UF permeate, but now the "pivot" point is around $300 \mathrm{Da}$ (see Figure 4). The permeate curve is very different from the feed solution because the molecular weight of the nanofiltration membrane is low compared to the MW range of the feed solution.

\subsubsection{Elastin hydrolysate FPH1 (Figures 5 and 6)}

Considering now the UF fractionation of the hydrolysate FPH1 (elastin), it is obvious that the permeate obtained had a composition close to that of $F P H 1$, although the VRF reached (10.6) was larger than for FPH2 (8.2). This resulted from the fact that FPH1 was more hydrolyzed than $\mathrm{FPH} 2$ so that the proportion of large peptides totally or strongly retained by the membranes was lower. The permeate passing through the membrane was not very different from FPH1, meaning that the MWCO of the UF membrane is not well-adapted for the fractionation of FPH1. It can be noted that this MWCO of $4000 \mathrm{Da}$ corresponds to the size of the largest peptides in $\mathrm{FPH} 1$. Another consequence is that the "pivot" point is slightly inferior to that observed for FPH2 (about 600 Da for FPH1 against 750 Da for FPH2).

As the UF permeates had close MW ranges for both hydrolysates $\mathrm{FPH} 1$ and $\mathrm{FPH} 2$ (see the discrete size-distribution in Table 2), the impact of NF fractionation was similar. The pivot point was still about $300 \mathrm{Da}$, and feed solution and permeate compositions were clearly different.

\subsubsection{Comparison}

The impact of UF was more effective for FPH2, less hydrolyzed than FPH1. That can be explained by comparing the membrane nominal cut-off $(4000 \mathrm{Da})$ with the $\mathrm{MW}$ range of peptides in hydrolysates. For FPH2, the biggest peptides had an MW of $7000 \mathrm{Da}$ (at $1.8 \%$ ), the most widely represented class of peptides - or median-size peptides - being around $1500 \mathrm{Da}$ (this corresponds to the maximum absorbance on Figure 3). The MWCO of the UF membrane ranges between this two values.

On the contrary, the most abundant class of peptides in FPH1 had an MW of about $350 \mathrm{Da}$, and the biggest peptides of about $4000 \mathrm{Da}$ (with a margin of $1.2 \%$ ) that corresponded exactly to the MWCO of the membrane. Thus, it can be concluded that the nominal MWCO of a UF membrane must range between those of the most abundant peptides and the biggest ones in order to obtain a good fractionation providing both a retentate and a permeate having composition significantly different from the raw hydrolysate.

It must be pointed out that UF and NF do not provide pure fractions even at high VRF. Thus, it is misleading to speak for instance of "the fraction 300-4000 Da" for the retentate obtained by 
processing the 4000 Da UF permeate by NF, as it is currently done in the literature, or of "the fraction above $4000 \mathrm{Da}$ " for the UF retentate. One must simply speak about enriched in such or such MW. Indeed, the NF retentate contained still $22 \%$ of peptides of MW < $300 \mathrm{Da}$ (the same value for $\mathrm{FPH} 1$ and $\mathrm{FPH} 2$ ), and the UF retentate contained still $86.5 \%$ (FPH1, elastine) to 92.5 $\%(\mathrm{FPH} 2, \mathrm{cod})$ of peptides $>4000 \mathrm{Da}$. However, if more refined fractions were wanted, they could be obtained by moving on to a diafiltration of the retentate but by dint of great pure water consumption.

\section{Conclusion}

This paper discusses the impact of a 2-step UF/NF fractionation process on two industrial FPH with different hydrolysis degrees having respectively peptides and free amino-acids in the MW ranges of 0-4000 Da and 0-7000 Da. Fractionation was performed in "realistic" conditions for an industrial process by processing FPH solutions with a high content in peptides until a high volume reduction factor was achieved. Peptidic profiles obtained by SEC-FPLC appeared to be a valuable tool to analyze the impact of the fractionation on the peptides composition of the $\mathrm{FPH}$.

It has also been proved that UF and NF did not provide pure fractions even at a high VRF, and that the populations obtained could not be characterized only by the cut-offs of the membranes used. Fractionation of FPHs by a UF 4000 Da provided a retentate enriched in peptides greater than about 600-750 Da and a permeate enriched in peptides lower than the same MW, meaning that the fractionation point is far below the nominal MWCO of the membrane claimed by the manufacturer. In addition, it has been found that the MWCO adapted to a fractionation process must be a bit lower than the MW of the biggest peptides. As a rule of thumb, the membrane MWCO can be chosen between the MW of the biggest and of the most abundant peptides in the $\mathrm{FPH}$.

Perspectives of this work are to control the impact of the operating parameters on the composition of the fractions obtained, mainly the volume reduction factor FRV and the transmembrane pressure $\Delta \mathrm{P}$. It could be interesting also to investigate other membrane materials in term of fouling and refining with the aim to lower the fouling and increase permeate fluxes. Finally, it is worth noting that pressure-driven tangential filtration can be coupled to other technologies to control the selectivity through charge effects. In particular, coupling ultrafiltration and electrodialysis has been proposed by Poulin et al. [39] for the selective fractionation of bioactive peptides from a $\beta$-lg tryptic hydrolysate in order to refine an anti-hypertensive and cationic peptide.

\section{Symbols and abbreviations}

$\mathrm{CF}$ - concentration factor

$\mathrm{C}_{0}$ - mass concentration (in NK) of the solution filtered

$\mathrm{c}_{\mathrm{m}}$ - concentration in solutes at the membrane wall

$\mathrm{C}_{\mathrm{Pf}}$ - mass concentration (in NK) of the final permeate sample

$\mathrm{C}_{\mathrm{R}}$ - mass concentration (in NK) of the concentrate recovered after filtration

$\mathrm{Da}$ - Dalton

$\mathrm{FPH}$ - fish protein hydrolysates

fs - filtered solution 
$\mathrm{J}_{\mathrm{v}, \mathrm{i}}$ - permeation flux at the beginning of the filtration

$\mathrm{J}_{\mathrm{v}, \mathrm{f}}$ - permeation flux at the end of the filtration

$\mathrm{R}_{\mathrm{a}}$ - apparent retention factor

$\mathrm{R}_{\mathrm{t}}$ - true retention factor

$L_{p}$ - water permeabilty

$m_{R}$ - mass of NK recovered in the retentate

$\mathrm{m}_{\mathrm{P}}$ - mass of NK recovered in the permeate

MWCO - Molecular Weight Cut-Off

NK - Nitrogen content

$\mathrm{NF}$ - nanofiltration

PES — polyethersulfone

$\mathrm{PS}$ - polysulfone

$\mathrm{RF}_{\mathrm{m}}, \mathrm{RF}_{\mathrm{f}}$ - mean and final retention factor

UF - ultrafiltration

$V_{0}$ - volume of the solution filtered

$V_{p}$ - volume of the average permeate

$V_{p^{\prime}}$ - volume of the final permeate sample

VRF — volume reduction factor

$\Delta \mathrm{P}$ - transmembrane pressure

$\Delta \Pi$ - change in osmotic pressure on both sides of the membrane

$\eta_{\mathrm{R}}$ - relative recovery in the retentate

$\sigma$ - reflexion coefficient

\section{Acknowledgements}

This study was performed within the SEAFOODplus European Integrated Programme (http://www.seafoodplus.org) as part of the "Propephealth" project 4.1. The Région Bretagne is thankfully acknowledged for a post-doctoral research grant within the ACTIVEMB project.

\section{References}

[1] P. Jaouen, M. Morancais-Bothorel and F. Quemeneur, Membrane filtration for waste protein recovery, Fish Processing Technology, Blackie and Son Limited Ed, 1992.

[2] L. Vandanjon, S. Cros, P. Bourseau and P. Jaouen, Recovery by nanofiltration and reverse osmosis of marine flavours from seafood cooking waters, Desalination, 144 (2002) 379-385.

[3] S. Cros, B. Lignot, P. Bourseau, P. Jaouen and C. Prost, Desalination of mussel cooking juices by electrodialysis: effect on the aroma profile, J. Food Eng. 69 (2005) 425-436.

[4] B. Lignot, V. Lahogue and P. Bourseau, Enzymatic extraction of Chondroitin Sulfate from skate cartilage and concentration-desalting by ultrafiltration, J. Biotechnol. 103 (2003) 281-284.

[5] FAO, The state of world fisheries and aquaculture, annual FAO report (2006).

[6] FAO, Discards in the world's marine fisheries: an update, FAO report (2004).

[7] H.G. Kristinsson and B.A. Rasco, Fish protein hydrolysates: production, biochemical, and functional properties, Crit. Rev. Food. Sci. Nutr. 40 (2000) (1) 43-81.

[8] L. Picot, S. Bordenave, S. Didelot, I. Fruitier-arnaudin, F. Sannier, G. Thorkelsson, J.P. Bergé, F. Guérard, A. Chabeaud and J.M. Piot, Antiproliferative activity of fish protein hydrolysates on human breast cancer cell lines, Process Biochem. 41 (2006) 1217-1222. 
[9] F. Guérard, D. Sellos and Y. Le Gal, Fish and shellfish upgrading, traceability advances in biochemical engineering, Biotechnol. 96 (2005) 127-163.

[10] J. Dumay, C. Donnay-Moreno, G. Barnathan, P. Jaouen and J.P. Bergé, Improvement of lipid and phospholipids recoveries from sardine (Sardina Pilchardus) viscera using industrial proteases, Process Biochem. 41 (2006) 2327-2332.

[11] J.Y. Je, Z.J. Qian, H.G. Byun and S.K. Kim, Purification and characterization of an antioxidant peptide obtained from tuna backbone protein by enzymatic hydrolysis, Process Biochem. 42 (2007) 840-846.

[12] S.Y. Kim, J.Y. Je and S.K. Kim, Purification and characterization of antioxidant peptide from hoki (johnius belengerii) frame protein by gastrointestinal digestion, J. Nutr. Biochem. 18 (2007) 31-38.

[13] V. Klompong, S. Benjakul, D. Kantachote and F.Shahidi, Antioxidative activity and functional properties of protein hydrolysate of yellow stripe trevally (Selaroides leptolepis) as influenced by the degree of hydrolysis and enzyme type, Food Chem. 102(4) (2007) 1317-1327. [14] F. Guérard, Enzymatic extraction methods for by-product recovery. In : F. Shahidi (Ed.). "Maximising the value of marine by-products", Part 2: By-products recovery and processing, Editions Woodhead, (2007) 107-143.

[15] L. Li, J. Wang, C. Cui and Y. Jiang, Artificial neural network for production of antioxidant peptides derived from bighead Carp muscles with alcalase, Food Technol. Biotechnol. 44 (2006) 441-448.

[16] A. Chabeaud, P. Dutournié, F. Guérard, L. Vandanjon and P. Bourseau, Design of Experiments (DOE) Methodology to Optimise the Antioxydant Activity of a Saithe (Pollachus Virens) Muscle Hydrolysate, submitted to Mar. Biotechnol. (2007).

[17] F. Guérard, M.T. Sumaya-Martinez, D. Laroque, A. Chabeaud and L. Dufossé, Optimization of Free Radical Scavenging Activity in the hydrolysis of shrimp processing discards by Response Surface Methodology, Process Biochem. 42 (2007) 1486-1491.

[18] A. Pihlanto, Antioxidative peptides derived from milk protein, Int. Dairy J. 16 (2006) 13061314.

[19] L. Gourley, S.F. Gauthier and Y. Pouliot, Separation of casein hydrolysates using polysulfone ultrafiltration membranes with $\mathrm{pH}$ and EDTA treatments applied, Lait 75 (1995), 259-269.

[20] Y. Pouliot, S. F. Gauthier and C. Bard, Fractionation of casein hydrolysates using polysulfone ultrafiltration hollow fiber membranes, J. Membrane Sci. 80 (1) (1993) 257-264.

[21] J.F. Lapointe, S.F. Gauthier, Y. Pouliot and C. Bouchard, Effect of hydrodynamic conditions on fractionation of $\beta$-lactoglobulin tryptic peptides using nanofiltration membranes, J. Membrane Sci. 212 (1-2) (2003) 55-67.

[22] F. Nau, F. L. Kerhervé, J. Leonil and G. Daufin, Selective separation of tryptic beta-casein peptides through ultrafiltration membranes: Influence of ionic interactions, Biotechnol. Bioeng. 46 (3) (1995) 246-253.

[23] H. C. Van der Horst, J. M. K. Timmer, T. Robbertsen and J. Leenders, Use of nanofiltration for concentration and demineralization in the dairy industry: Model for mass transport, $\mathrm{J}$. Membrane Sci. 104 (3) (1995) 205-218.

[24] F. Lebrun, A. Bazus, P. Dhulster and D. Guillochon, Influence of molecular interactions on ultrafiltration of a bovine hemoglobin hydrolysate with an organic membrane, J. Membrane Sci. 146 (1) (1998) 113-124.

[25] S. Bérot, Y. Popineau, J.-P. Compoint, C. Blassel and B. Chaufer, Ultrafiltration to fractionate wheat polypeptides, J. Chromatogr. 753 (2001) 29-35.

[26] B. Tessier, C. Harscoat-Schiavo and I. Marc, Contribution of electrostatic interactions during fractionation of small peptides complex mixtures by UF/NF membranes, Desalination, 200 (1-3) (2006) 333-334. 
[27] N. D'Alvise, C. Lesueur-Lambert, B. Fertin, P. Dhulster and D. Guillochon, Hydrolysis and large scale ultrafiltration study of alfalfa protein concentrate enzymatic hydrolysate, Enzyme Microb. Tech. 27 (2004) 286-294.

[28] Y.J. Jeon, H.G. Byun and S.K. Kim, Improvement of functional properties of cod frame protein hydrolysates using ultrafiltration membranes, Process Biochem. 35 (1999) 471-478.

[29] S.K. Kim, Y.T. Kim, H.G. Byun, K.S. Nam, D.S. Joo and F. Shahidi, Isolation and characterisation of antioxidative peptides from gelatine hydrolysate of Alaska Pollack skin, J. Agr. Food Chem. 49 (4), (2001) 1984-1989.

[30] T. Wang, T.Q. Zeng and Y. Ye, Application of ultrafiltration in separation of scallop skirt enzymatic hydrolysates, J. Fish. Sci. China 9(3) (2002) 255-259.

[31] L. Vandanjon, R. Johannsson, M. Derouiniot, P. Jaouen and P. Bourseau, Concentration and purification by ultrafiltration of marine peptides solutions, J. Food Eng. 83 (2007) 581-589.

[32] R.I. Fenton-May, C.G. Hill and C.H. Amundson, Use of ultrafiltration and reverse osmosis systems for the concentration and fractionation of whey, J. Food Sci. 36 (1971) 14-21.

[33] S. Bouhallab and C. Touzé, Continuous hydrolysis of caseinomacropeptide in a membrane reactor - kinetic-study and gram-scale production of antithrombotic peptides, Lait 75 (3) (1995) 251-258.

[34] N. Lajoie, S.F. Gauthier and Y. Pouliot, Improved storage stability of model infant formula by whey peptides fractions, J. Agr. Food Chem. 49 (2001) 1999-2007.

[35] F. Guérard, L. Dufosse, D. De La Broise and A. Binet, Enzymatic hydrolysis of proteins from yellowfin tuna (Thunnus albacares) wastes using Alcalase, J. Mol. Catal. B : Enzym. 11 (2001) 1051-1059.

[36] F. Guérard, A. Chabeaud, D. Laroque, A. Denes, L. Vandanjon, N. Decourcelle and P. Bourseau, Size exclusion chromatography: a useful and versatile tool for quantitative analysis of fish protein hydrolysates, submitted to Process Biochem. (2007).

[37] M. Cheryan, Ultrafiltration and microfiltration handbook, Technomic Publishing Co, Inc., Lancaster, USA, (1998).

[38] S. Cros, B. Lignot, P. Bourseau and P. Jaouen, Technical and economical evaluation of a membrane process capable both to produce an aroma concentrate and to reject clean water from shrimp cooking juices, J. Food Eng. 77 (2006) 697-707.

[39] J.-F. Poulin, J. Amiot and L. Bazinet, Simultaneous separation of acid and basic bioactive peptides by electrodialysis with ultrafiltration membrane, J. of Biotechnol. 123 (3) (2006), 314328. 


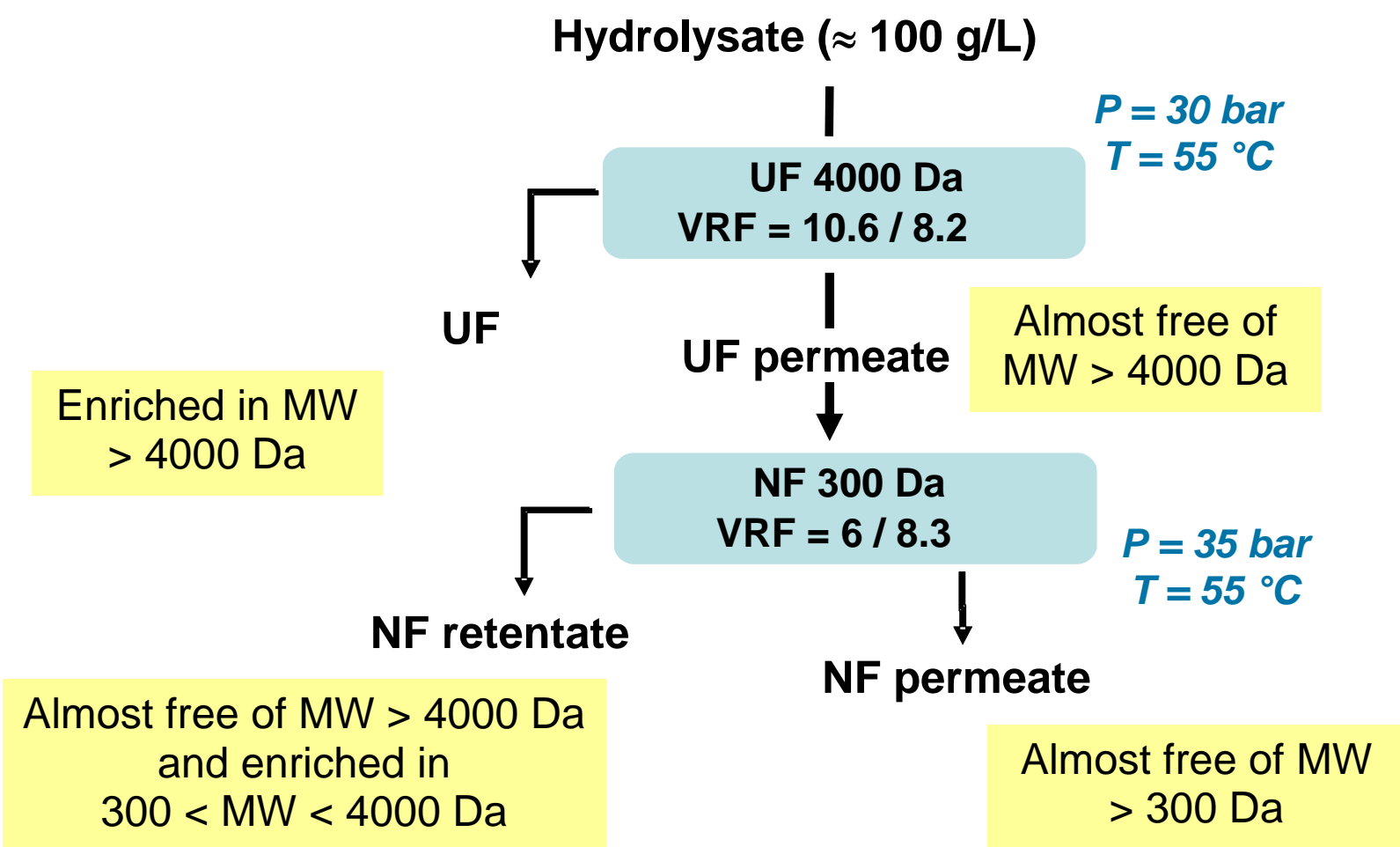

Fig. 1. The ultrafiltration-nanofiltration sequence (N.B. : molecular weight given here (300, 4000) are only indicative values based on nominal MWCO membrane claimed by manufacturers). 


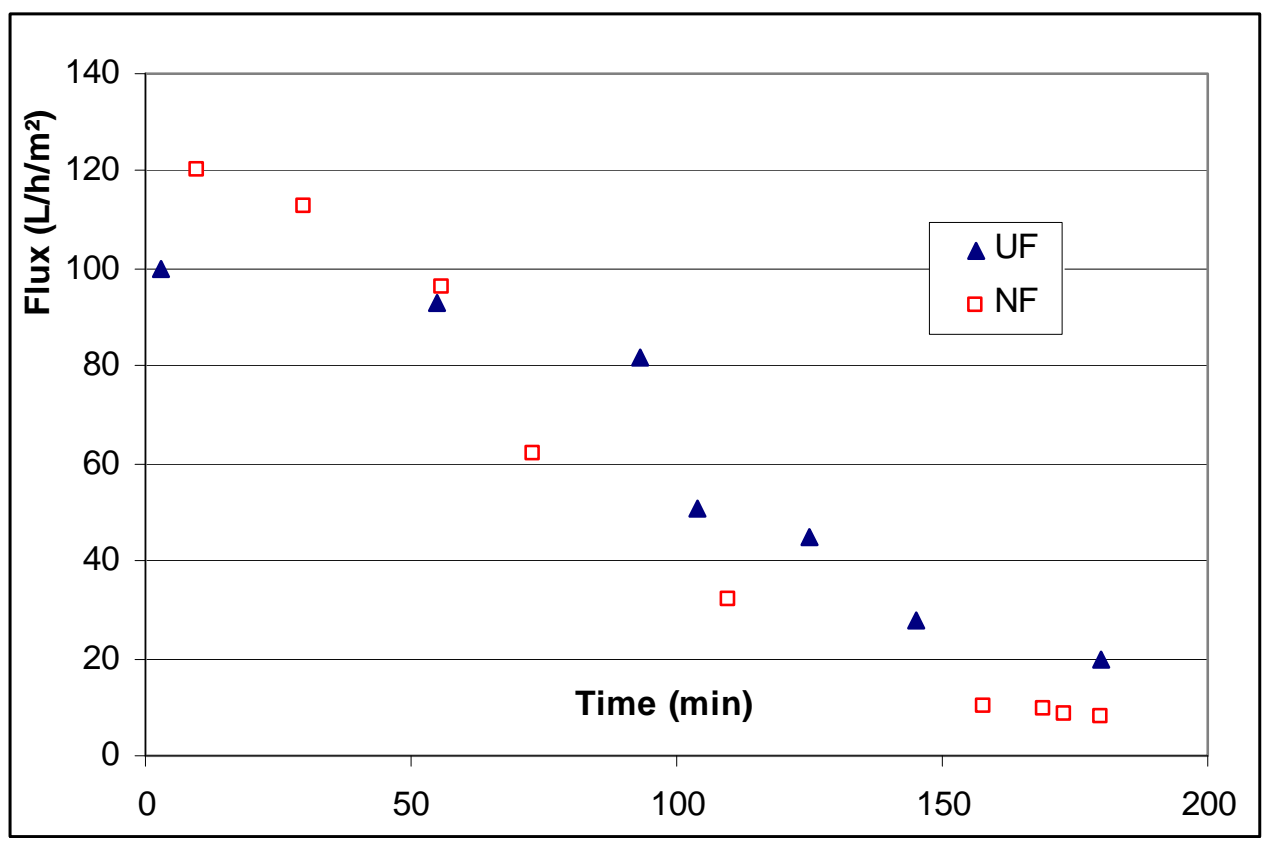

Fig. 2. Flux evolution with time for the UF and NF steps; PROLASTIN hydrolysate (FPH1)

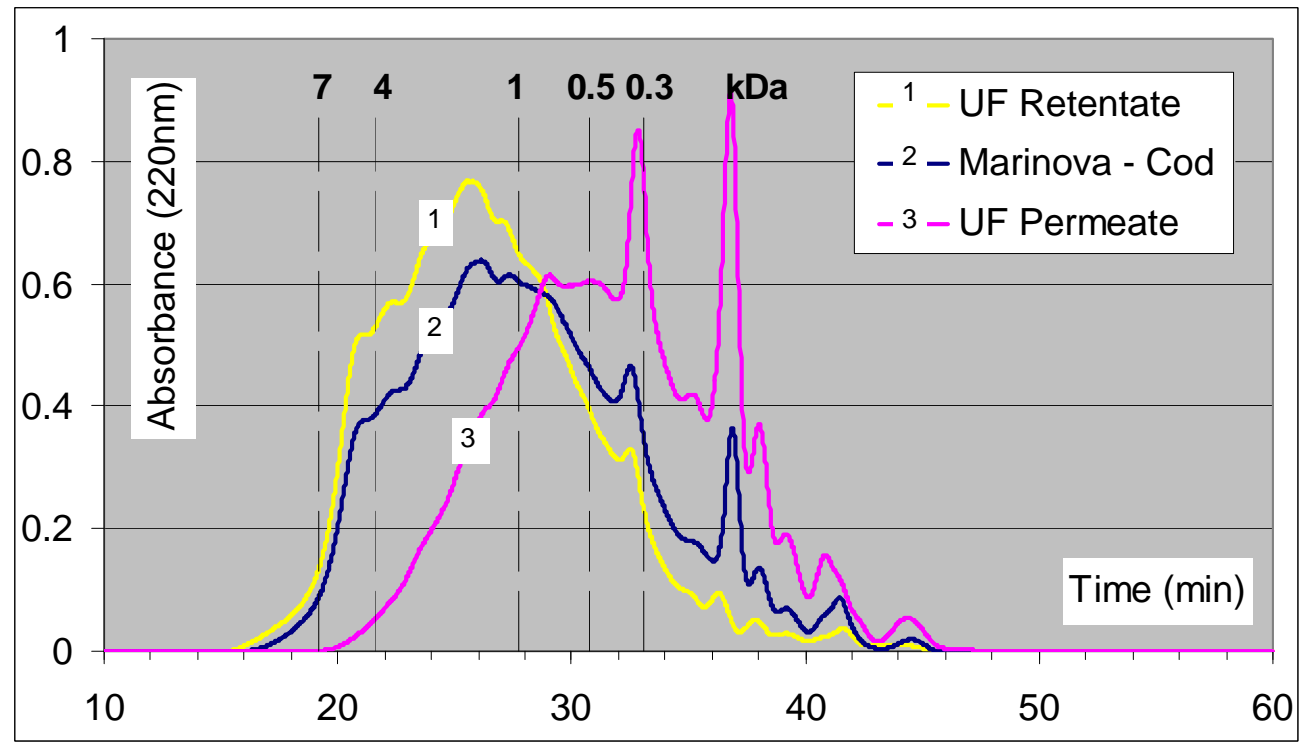

Fig. 3. « Normalized » chromatograms of fractions involved in the UF fractionation of MariPep C hydrolysate (FPH2); middle curve 2 is the feed solution, left curve 1 the retentate and right curve 3 the permeate; VRF $=8.2, \mathrm{CF}=4.2$. 


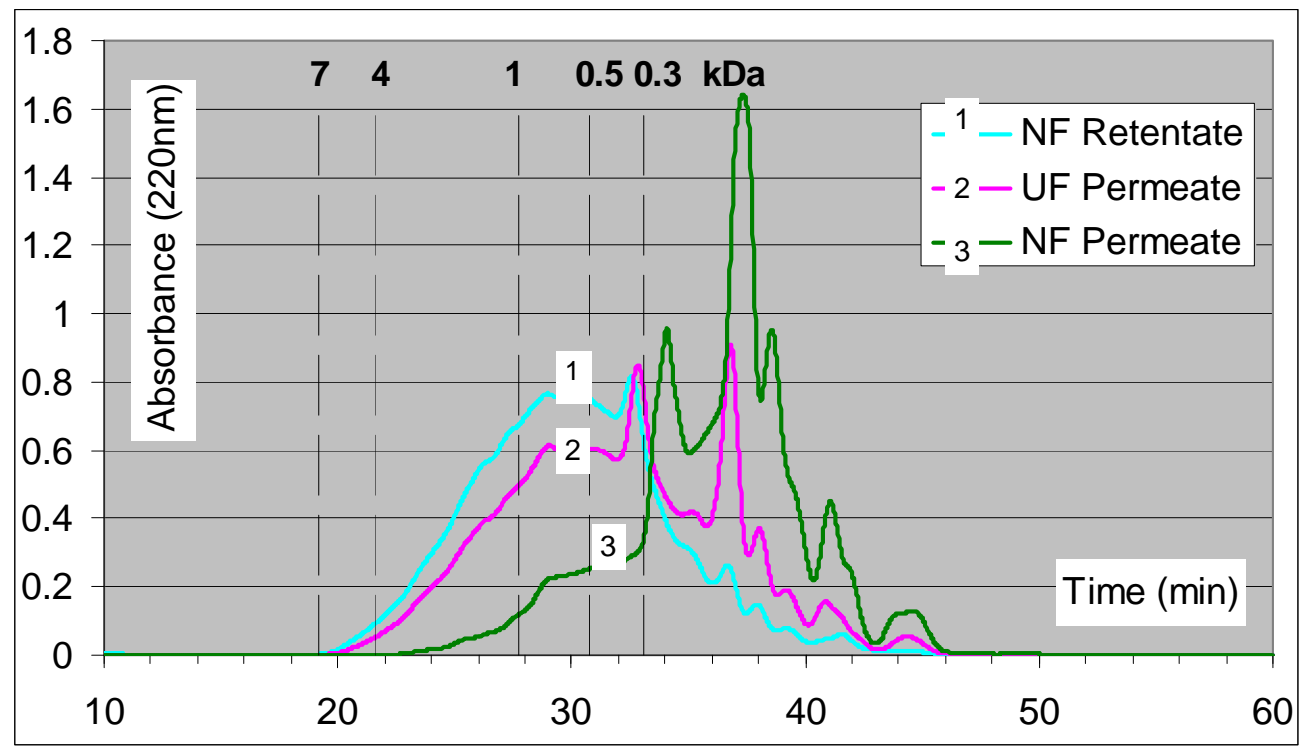

Fig. 4. «Normalized » chromatograms of fractions involved in the NF fractionation of the permeate obtained by UF fractionation of MariPep C hydrolysate (FPH2); middle curve 2 is the feed solution, left curve 1 the retentate and right curve 3 the permeate; VRF = 8.3, CF = 7.2.

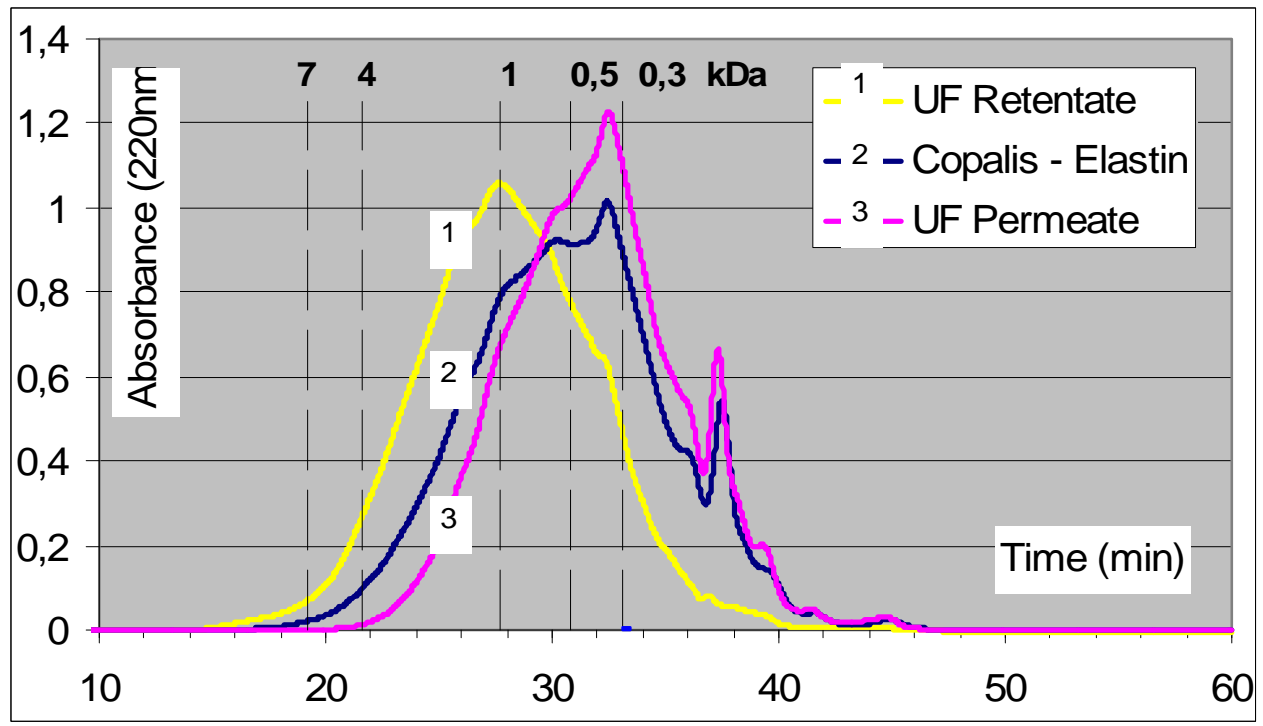

Fig. 5. «Normalized » chromatograms of fractions involved in the UF fractionation of PROLASTIN hydrolysate (FPH1); middle curve 2 is the feed solution, left curve 1 the retentate and right curve 3 the permeate; $\mathrm{VRF}=10.6, \mathrm{CF}=3.4$. 


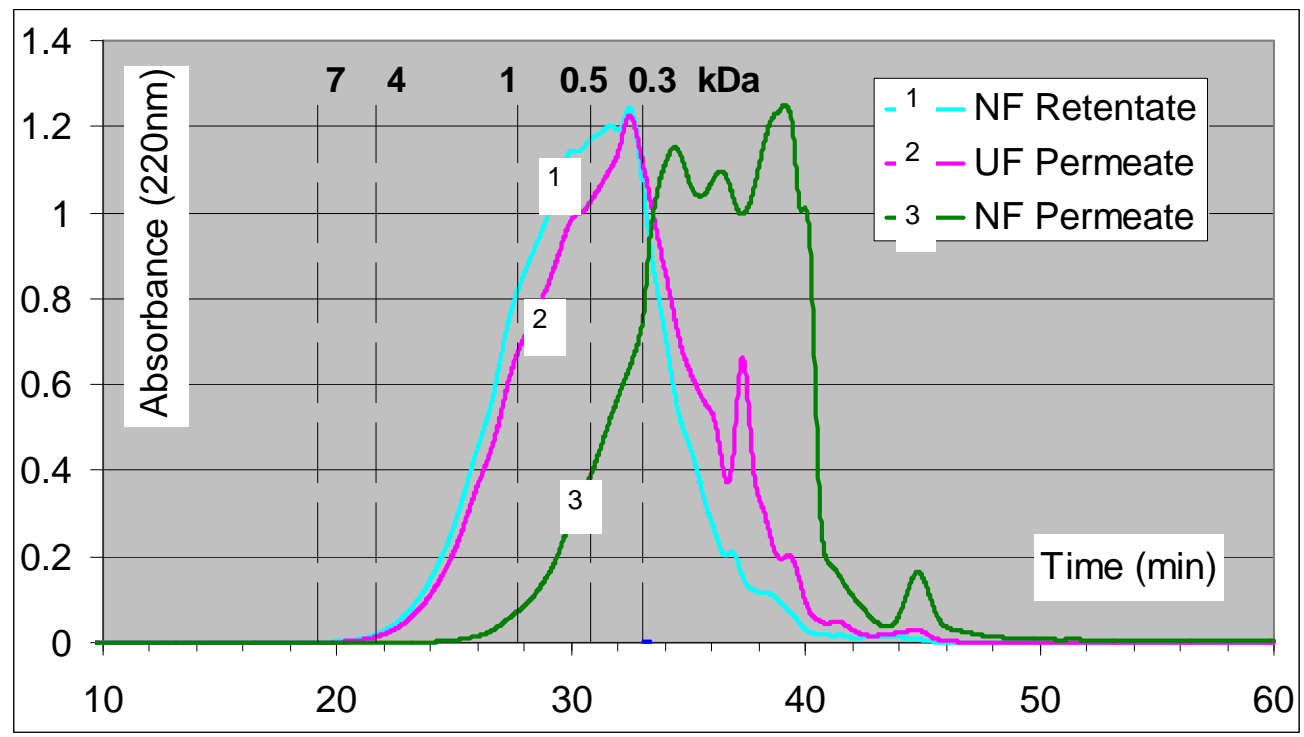

Fig. 6. «Normalized » chromatograms of fractions involved in the NF fractionation of the permeate obtained by UF fractionation of PROLASTIN hydrolysate (FPH1); middle curve 2 is the feed solution, left curve 1 the retentate and right curve 3 the permeate; VRF $=6, C F=4.6$.

\section{Tables}

Table 1

Physical properties of the hydrolysates and their UF/NF fractions (ND: not determined)

\begin{tabular}{|c|c|c|c|c|c|c|c|}
\hline \multirow{2}{*}{\multicolumn{5}{|c|}{ PROLASTIN (FPH1) }} & \multirow{2}{*}{\multicolumn{3}{|c|}{$\mathrm{g} / 100 \mathrm{~g}$ of powder }} \\
\hline & & & & & & & \\
\hline & colour & Odour & Solubility & $\mathrm{pH}$ & $\mathrm{NaCl}$ & $\begin{array}{l}\text { Nitrogen } \\
\text { NK }\end{array}$ & $\begin{array}{l}\text { Protein, } \\
\text { NK } \times 6.25\end{array}$ \\
\hline Crude extract (FPH1) & $\begin{array}{l}\text { Yellow } \\
\text { orange }\end{array}$ & Low & $100 \%$ & 8.0 & 0.73 & 14.2 & 88.5 \\
\hline Retentate UF $4000 \mathrm{Da}$ & $\begin{array}{l}\text { Yellow } \\
\text { orange } \\
\end{array}$ & Low & $100 \%$ & 7.9 & 0.06 & 14.5 & 90.9 \\
\hline Permeate UF $4000 \mathrm{Da}$ & Yellow & Low & $100 \%$ & 7.9 & 1.05 & 13.1 & 81.6 \\
\hline Retentate NF $300 \mathrm{Da}$ & Yellow & Low & $100 \%$ & 7.9 & 0.09 & 14.6 & 91.3 \\
\hline Permeate NF $300 \mathrm{Da}$ & Yellow & Low & $100 \%$ & 8.1 & 3.65 & 11.4 & 71.1 \\
\hline \multirow[t]{2}{*}{ MariPep C (FPH2) } & & & & & \multicolumn{3}{|c|}{$\mathrm{g} / 100 \mathrm{~g}$ of powder } \\
\hline & colour & Odour & Solubility & $\mathrm{pH}$ & $\mathrm{NaCl}$ & $\begin{array}{l}\text { Nitrogen } \\
\text { NK }\end{array}$ & $\begin{array}{l}\text { Protein, } \\
\text { NK } \times 6.25\end{array}$ \\
\hline Crude extract (FPH2) & Yellow & Low & $100 \%$ & 6.9 & 19.5 & 11.7 & 73.12 \\
\hline Retentate UF $4000 \mathrm{Da}$ & Brown & Low & $100 \%$ & 7.0 & 4.73 & 13.5 & 84.38 \\
\hline Permeate UF $4000 \mathrm{Da}$ & Yellow & Low & $100 \%$ & 6.9 & 38.7 & 10.8 & 67.50 \\
\hline Retentate NF $300 \mathrm{Da}$ & Yellow & Low & $100 \%$ & 6.8 & 8.84 & 13.6 & 85.00 \\
\hline Permeate NF 300 Da & $\begin{array}{l}\text { Colorles } \\
\mathrm{s}\end{array}$ & Low & $100 \%$ & 7.0 & 64.60 & 4.0 & 25.00 \\
\hline
\end{tabular}


Table 2

Discrete size-distribution of the hydrolysates and their UF/NF fractions (the proportion of various classes are given in $w / w \%$ )

\begin{tabular}{|c|c|c|c|c|c|c|c|c|c|c|}
\hline & Duration & VRF & CF & $\mathrm{RF}_{\mathrm{m}}$ & $R F_{f}$ & $\eta_{\mathrm{R}}$ & $\begin{array}{c}\text { Normalized } \\
\text { Water } \\
\text { Permeability } L_{p}\end{array}$ & $\mathrm{~J}_{\mathrm{v}, \mathrm{i}}$ & $J_{v, f}$ & $\mathrm{~J}_{\mathrm{v}, \mathrm{I}} / \Delta \mathrm{P}$ \\
\hline & $(\min )$ & & & & & & $\left(L \cdot m^{-2} \cdot h^{-1} \cdot\right.$ bar $\left.^{-1}\right)$ & $\begin{array}{l}\left(\mathrm{L} \cdot \mathrm{m}^{-2}\right. \\
\left(m^{3} \cdot \mathrm{m}\right.\end{array}$ & $\begin{array}{l}\left.2^{2} \cdot h^{-1}\right) \\
\left.{ }^{2} \cdot s^{-1}\right)\end{array}$ & $\left(L \cdot m^{-2} \cdot h^{-1} \cdot\right.$ bar $\left.^{-1}\right)$ \\
\hline \multicolumn{11}{|l|}{ PROLASTIN (FPH1) } \\
\hline UF $\left(30\right.$ bar, $\left.55^{\circ} \mathrm{C}\right)$ & 180 & 10.6 & 3.4 & $52 \%$ & $30 \%$ & $31 \%$ & $15.7\left(30^{\circ} \mathrm{C}\right)$ & $\begin{array}{c}100 \\
(27.8)\end{array}$ & $\begin{array}{c}20 \\
(5.6)\end{array}$ & 3.3 \\
\hline $\mathrm{NF}\left(35 \mathrm{bar}, 55^{\circ} \mathrm{C}\right)$ & 180 & 6.0 & 4.6 & $85 \%$ & $60 \%$ & $77 \%$ & $5.0\left(40^{\circ} \mathrm{C}\right)$ & $\begin{array}{c}120 \\
(33.3)\end{array}$ & $\begin{array}{c}8 \\
(2.2)\end{array}$ & 3.4 \\
\hline \multicolumn{11}{|l|}{ MariPep C (FPH2) } \\
\hline UF $\left(30\right.$ bar, $\left.55^{\circ} \mathrm{C}\right)$ & 360 & 8.2 & 4.2 & $69 \%$ & $71 \%$ & $64 \%$ & $19.4\left(30^{\circ} \mathrm{C}\right)$ & $\begin{array}{c}105 \\
(19.2)\end{array}$ & $\begin{array}{c}10 \\
(2.8)\end{array}$ & 3.5 \\
\hline NF $\left(35\right.$ bar, $\left.55^{\circ} \mathrm{C}\right)$ & 105 & 8.3 & 7.2 & $93 \%$ & $85 \%$ & $71 \%$ & $5.6\left(25^{\circ} \mathrm{C}\right)$ & $\begin{array}{c}160 \\
(44.4)\end{array}$ & $\begin{array}{c}26 \\
(7.2)\end{array}$ & 4.6 \\
\hline
\end{tabular}

Table 3

Performance of hydrolysates ultrafiltration and nanofiltration: volume reduction factor, VRF, concentration factor, $C F$, mean and final retention rate, $R_{F}$ an $R_{f}$, relative recovery of peptides in the retentate, $\eta_{R}$, water permeability before filtration, $L_{p}$, initial and final permeation fluxes, $J_{v, i}$ and $J_{v, f}$, and initial permeability, $J_{v, i} / \Delta P$.

\begin{tabular}{c|ccccc} 
Molecular weight (Da) & $>7000$ & $\begin{array}{c}7000- \\
4000\end{array}$ & $\begin{array}{c}4000- \\
1000\end{array}$ & $1000-300$ & $<300$ \\
\hline \hline PROLASTIN (FPH1) & 0.23 & 1.18 & 23.28 & 45.78 & 29.54 \\
\hline \hline & & & & & \\
\hline UF Permeate & 0.02 & 0.08 & 13.9 & 49.66 & 36.33 \\
UF Retentate & 3.98 & 3.48 & 41.15 & 41.55 & 9.84 \\
\hline \hline NF Permeate & 0 & 0 & 0.74 & 17.79 & 81.47 \\
NF Retentate & 4.85 & 0.09 & 17.49 & 55.78 & 21.78 \\
& & & & & \\
MariPep C (FPH2) & 1.16 & 8.23 & 40.58 & 32.84 & 17.19 \\
\hline \hline UF Permeate & 0 & 0,58 & 19.65 & 39.99 & 39.78 \\
UF Retentate & 2.06 & 11.46 & 50.01 & 28.94 & 7.53 \\
\hline \hline NF Permeate & 0 & 0 & 2.72 & 15.43 & 81.84 \\
NF Retentate & 0.04 & 1.14 & 28.66 & 48.51 & 21.64
\end{tabular}


Table 4

Balances in volume and nitrogen (NK) on the UF and NF of hydrolysates FPH1 and FPH2

\begin{tabular}{|c|c|c|c|c|c|c|c|}
\hline \multicolumn{2}{|c|}{ PROLASTIN (FPH1) } & $\begin{array}{l}\mathrm{V} \\
(\mathrm{L})\end{array}$ & $\begin{array}{c}\text { Nitrogen } \\
\text { Kjeldahl, } c_{1} \\
(\mathrm{~g} / \mathrm{L})\end{array}$ & $\begin{array}{l}\text { Nitrogen } \\
\text { Kjeldahl (g) }\end{array}$ & $\begin{array}{c}\text { Nitrogen } \\
\text { FPLC, } c_{2} \\
(\mathrm{~g} / \mathrm{L})\end{array}$ & $\begin{array}{l}\text { Nitrogen } \\
\text { SEC-FPLC } \\
\text { (g) }\end{array}$ & $\begin{array}{c}\text { Absolute } \\
\text { difference } \\
\left|\mathrm{c}_{1}-\mathrm{c}_{2}\right|(\mathrm{g} / \mathrm{L})\end{array}$ \\
\hline \multicolumn{2}{|c|}{ Amounts and concentrations } & & & & & & \\
\hline \multirow{4}{*}{ UF } & Crude extract (FPH1) & 9 & 14.5 & 130.5 & 13.2 & 118.4 & 1.3 \\
\hline & Retentate UF & 0.74 & 49.0 & 36.3 & 58.8 & 43.5 & 9.8 \\
\hline & Permeate UF & 8.1 & 9.89 & 80.1 & 9.37 & 75.9 & 0.5 \\
\hline & Final permeate UF & 0.05 & 34.2 & 1.7 & $n m^{(*)}$ & n.m. & \\
\hline \multirow{4}{*}{ NF } & Permeate UF & 7 & 9.89 & 69.2 & 9.37 & 65.6 & 0.5 \\
\hline & Retentate NF & 1.12 & 45.1 & 50.5 & 44.4 & 49.8 & 0.7 \\
\hline & Permeate NF & 5.8 & 2.59 & 15.0 & 1.78 & 10.3 & 0.8 \\
\hline & Final permeate NF & 0.03 & 17.9 & 0.5 & $n m^{(*)}$ & 0.5 & \\
\hline $\begin{array}{l}\text { UF balance } \\
\text { residues }\end{array}$ & $\begin{array}{c}\text { absolute } \\
\text { (percentage) }\end{array}$ & $\begin{array}{c}0.11 \\
(1.2 \%) \\
\end{array}$ & & $\begin{array}{c}12.4 \\
(9.5 \%)\end{array}$ & & $\begin{array}{c}-2.7 \\
(-2.3 \%)\end{array}$ & \\
\hline $\begin{array}{l}\text { NF balance } \\
\text { residues }\end{array}$ & $\begin{array}{c}\text { absolute } \\
\text { (percentage) }\end{array}$ & $\begin{array}{c}0.05 \\
(0.7 \%)\end{array}$ & & $\begin{array}{c}3.2 \\
(5 \%)\end{array}$ & & $\begin{array}{c}5.0 \\
(8 \%)\end{array}$ & \\
\hline
\end{tabular}

${ }^{(*)} \mathrm{nm}$ : not measured

\begin{tabular}{|c|c|c|c|c|c|c|c|}
\hline \multicolumn{2}{|c|}{ MariPep C (FPH2) } & $\begin{array}{l}\mathrm{V} \\
(\mathrm{L})\end{array}$ & $\begin{array}{c}\text { Nitrogen } \\
\text { Kjeldahl, } c_{1} \\
(\mathrm{~g} / \mathrm{L})\end{array}$ & $\begin{array}{c}\text { Nitrogen } \\
\text { Kjeldahl (g) }\end{array}$ & $\begin{array}{l}\text { Nitrogen } \\
\text { FPLC, } C_{2} \\
(\mathrm{~g} / \mathrm{L})\end{array}$ & $\begin{array}{c}\text { Nitrogen } \\
\text { SEC-FPLC } \\
(\mathrm{g})\end{array}$ & $\begin{array}{c}\text { Absolute } \\
\text { difference } \\
\left|\mathrm{c}_{1}-\mathrm{C}_{2}\right|(\mathrm{g} / \mathrm{L})\end{array}$ \\
\hline \multicolumn{8}{|c|}{ Amounts and concentrations } \\
\hline \multirow{4}{*}{ UF } & Crude extract (FPH2) & 9 & 11.4 & 102.4 & 10.9 & 98.4 & 0.5 \\
\hline & Retentate UF & 1.1 & 48.2 & 53.0 & 42.2 & 46.5 & 6.0 \\
\hline & Permeate UF & 7.89 & 3.77 & 29.7 & 3.58 & 28.2 & 0.2 \\
\hline & Final permeate UF & 0.01 & 14.2 & 0.1 & n.m. & 0.1 & \\
\hline \multirow{4}{*}{ NF } & Permeate UF & 7 & 3.77 & 26.4 & 3.58 & 25.1 & 0.2 \\
\hline & Retentate NF & 0.71 & 27.1 & 19.3 & 28.9 & 20.5 & 1.8 \\
\hline & Permeate NF & 6.11 & 1.12 & 6.8 & 1.09 & 6.7 & 0.03 \\
\hline & Final permeate NF & 0.05 & 4.03 & 0.2 & n.m. & 0.2 & \\
\hline \multirow{2}{*}{$\begin{array}{l}\text { UF balance } \\
\text { residues }\end{array}$} & absolute & $0 \mathrm{~L}$ & & 19.6 & & 23.5 & \\
\hline & (percentage) & $0 \%$ & & $(19 \%)$ & & $(24 \%)$ & \\
\hline $\begin{array}{l}\text { NF balance } \\
\text { residues }\end{array}$ & $\begin{array}{c}\text { absolute } \\
\text { (percentage) }\end{array}$ & $\begin{array}{c}0.13 \\
(2 \%)\end{array}$ & & $\begin{array}{c}0.04 \\
(0.2 \%)\end{array}$ & & $\begin{array}{c}-2.3 \\
(-9 \%)\end{array}$ & \\
\hline
\end{tabular}

